\title{
Resisting Nationalism: \\ Understanding Thomas Pynchon's Postnational Vision From Mason Ev Dixon To Against The Day
}

Ali Dehdarirad*

\begin{abstract}
The creation of so-called alternative worlds in his fiction has been seminal in establishing Thomas Pynchon as a postmodern writer. From the mysterious worlds of lady V. and the Tristero postal system in his early novels to the fictive worlds of a sailing airship beneath desert sand and the Deep Web and the software DeepArcher in his later fiction, these alternative realities have been investigated by distinguished critics from different points of view. Regarding the possibility of a post-national imagination in Pynchon's fiction, in relation to his alternative worlds, several acclaimed scholars have prominently addressed this issue. Nevertheless, the narrative of Against the Day still needs to be meticulously analysed. This essay aims to investigate how Pynchon's post-national vision calls into question and resists the overreaching metanarrative of nationalism in the world. By analysing the alternative realities, in connection with the issue of temporality, this essay attempts to depict the instantiation and development of a post-national vision from Mason E Dixon to Against the Day which questions the long-established dominance of nationalism in the world.
\end{abstract}

Key words: Thomas Pynchon, Post-nationalism, Alternative worlds, Temporality, Against the day, Mason E'Dixon

\footnotetext{
* Sapienza University of Rome; ali.dehdarirad@uniroma1.it
} 


\section{Introduction}

In episode 35 of Thomas Pynchon's Mason E' Dixon we learn from the Reverend Cherrycoke how the members of the British Royal Society, and their French counterparts, "preach" $(1997,347)$ the invaluable significance of "Reason" over other explanations of the world's matters:

Royal Society members and French Encyclopaedists are in the Chariot, availing themselves whilst they may - of any occasion to preach the Gospels of Reason, denouncing all that once was Magic, though too often in smirking tropes upon the Church of Rome, - visitations, bleeding statues, medical impossibilities, - no, no, far too foreign. One may be allowed an occasional Cock Lane Ghost, — otherwise, for any more in that Article, one must turn to Gothick Fictions, folded acceptably between the covers of Books.

As a consequence of such a stand by the Royal Society, the Reverend mentions, "These times are unfriendly toward Worlds alternative to this one." This short, but meaningful, passage from Mason E' Dixon might encapsulate what lies at the centre of Pynchon's post-national vision in the novel. Moving from this premise as the essence of my analysis, I am going to tackle three significant issues in the introduction which I will be using throughout my paper: the question of alternative worlds, what post-nationalism means in my essay, and the relation between Pynchon's alternative realities and the postnational phenomena in Mason Eं Dixon and Against The Day.

\section{Pynchon's Alternative Worlds}

Thomas Pynchon has been very salient in creating so-called alternative worlds in his fiction which, amongst other things, question the hegemony of the nation-state as the only form of envisioning our lifeworlds. What constitutes these alternative realities are imaginary spaces, imagined by Pynchon in almost all of his novels, which suggest new modes of organising the world. In order to better understand what a world is, I am going to provide a brief account of Thomas Pavel's definition of an ontology, based on which Brian McHale has developed his understanding of a world. McHale's definition of a world, in conjunction with Pavel's explanation of an ontology, is essential in understanding Pynchon's multiple worlds. 
In 1981, Pavel described an ontology as "a theoretical description of a universe" (234). Drawing on this definition, McHale, in Postmodernist Fiction, emphasises that "the operative word in Pavel's definition [...] is the indefinite article: an ontology is a description of a universe, not of the universe; that is, it may describe any universe, potentially a plurality of universes" $(1987,27)$. He observes that an ontology might "involve describing other universes" and not necessarily "seek some grounding for our universe." Seen in this light, it can refer to the description of "'possible' or even 'impossible' universesnot least of all the other universe, or heterocosm, of fiction." Since "the dominant of postmodernist fiction is ontological" (10), it can be argued that there is a strict relation between the use of alternative worlds and the category of literary postmodernism.

As far as Pynchon is concerned, his role in establishing the category of postmodernism in literature has been seminal. To begin with, in his famous essay on postmodernism, in 1991, Fredric Jameson provided a shortlist of exemplary postmodernists which includes Pynchon together with some other iconic postmodern figures. The inclusion of Pynchon on Jameson's shortlist is very telling in so far as, after having mentioned a few of the most representative names, he posits that "the list might be extended indefinitely" (1). In 2007, Rachel Adams observed that "Thomas Pynchon may be the most frequently cited author in the vast scholarship on literary postmodernism” (252). Although there is no consensus over the definition of postmodernism, in 2012, McHale observed that "the fiction of Thomas Pynchon appears to be universally regarded as central to its canon" (97). Pynchon's peculiar fiction is very vast in scope. Its author's knowledge is surprisingly formidable on a host of various topics. Its characters are delightfully intriguing, and its narrative is complex and comprehensive. As such, this bizarrely all-encompassing fiction does not lend itself to any particular genre, school, or trend. However, one reason for McHale's observation seems to be Pynchon's conceiving of those alternative worlds that allow for ontological plurality. Indeed, his alternative realities are in large part, in William Ashline's words, "transgressions of ontological levels" $(1995,218)$.

In A Hacker Manifesto, McKenzie Wark observes that an important characteristic of a world is "potential" $(2004,175)$, as opposed to "necessity" (170). This view suggests that a world can potentially set in motion alternative ways of understanding the world as we know it. Consequently, other modes of existence can thrive without being subordinated to a single hegemonic order. In such a condition, an ontology, in the sense of a potential "plurality of universes" (McHale 1987, 27), might become possible. Within this ontological plurality, the alternative worlds can be described as "alternative subcultures, life-styles, values-systems, enclaves of meaning, psychological realities” (2007, 49) that would go beyond the calcified epistemology of any overreaching order such as the 
national ideology. In what follows, I provide a quick view of some exemplary representations of Pynchon's alternative realities in his fiction: the apparent manipulation of reality by the travels of the elusive lady $\mathrm{V}$. in his debut novel $V$., the mysterious underground Tristero system in The Crying of Lot 49, the angels, the Thanatoids, and the ghosts in Vineland, the hollow earth in Mason $E^{2}$ Dixon, the sailing airships traveling beneath desert sand or through the world via Symmes' Hole in Against The Day, and the Deep Web and the software DeepArcher in his most recent novel, Bleeding Edge.

\section{Understanding Post-nationalism}

In a scene near the end of Against the Day's narrative, Penny Black explains to the Chums of Chance, "a five-lad crew belonging to that celebrated aeronautics club known as the Chums of Chance" (Pynchon 2006, 8), the meaning of the Garçons de '71's motto, “"There, but Invisible" (1087). A member of a group of balloonists from Oregon, she mentions that "the Boys call it the supranational idea" which is "literally to transcend the old political space, the map-space of two dimensions, by climbing into the third.” This quotation exposes very eloquently, perhaps, the most post-national vision in Pynchon's novel. "The supranational idea" is the suggestion of envisaging alternative ways of understanding, interpreting, and organising the world other than the overruling "old political space." This view substantially recapitulates what I mean by a post-national vision in the novel. Nevertheless, for the sake of a theoretical basis, I shall explain in more detail what the term post-nationalism stands for in my essay.

Sascha Pöhlmann has used the term "nation-ness" $(2010,7)$ to refer to the concept of the nation. The reason for his choice is to distinguish the abstract idea of the nation from its prevalent use to refer to a person's nationality. With this abstract concept of "nationness" in mind, the term post-nationalism in my essay refers to "anything that works towards dismantling the hegemony of nation-ness as a metanarrative" (Pöhlmann 2010, 8). The counterhegemonic outlook of such a post-national vision actively attempts to imagine the nationalised world through different lenses of epistemological understanding and ontological possibilities. By constantly questioning the overreaching power of the national metanarrative in the world, this sort of post-national imaginary tries to delegitimise "nation-ness" (7) and contest its hegemonic status.

Nonetheless, it must be remembered that questioning the legitimacy of "nation-ness" and challenging its dominant position, through a post-national imagination, does not mean refusing the existence and the reality of nations. In fact, what the post-nationalists in American Studies propose is "a different framework for reading the nation as well as a 
critical practice that moves beyond the nationalist and exceptionalist framework" (14). Hence, in this essay the prefix post in the term post-nationalism does not mean after. Put otherwise, post-nationalism does not equal after nationalism. Indeed, post-nationalism seeks to provide insight into how to dispose of the hegemonic role of "nation-ness" (7) as a dominant concept of order in the world. Defined in this way, post-nationalism explicitly aims to question "the hegemony of the national, its myths and narratives, its discourses and categories, its fixed identities and its mechanisms of control” (16).

\section{The Alternative Worlds and Post-nationalism}

The question of alternative worlds in Pynchon's fiction, and its relevance to the category of postmodernism, has been discussed by many critics. However, one important issue concerning these alternative realities in his fiction, which still seems to be a matter of disagreement between critics, is whether they suggest a post-national vision. Concentrating on transatlantic phenomena, in 2002, Paul Giles proposed a transnational approach to American Studies by way of analysing "points of intersection between the United States and Great Britain" (1). He observed that it is "premature" (20) to speak "in post-national terms" in a world where the nation, "as a category of affiliation and analysis," is still dominant. Regarding Pynchon's novels, he suggests that they offer a "specifically transnational rather than postnational" (237) imagination. For instance, he holds that Mason $\sigma^{\circ}$ Dixon deals with "transnational crossings and the traversal of stable national boundaries" (246).

Analysing the works of Thomas Pynchon and Carlos Fuentes, through a "comparativist approach to the contemporary American and Mexican literary canons" (IV), in 2014, Pedro García-Caro argued that these novels offer a "postnational satire" (VI). As he endeavours to show, these are works that attempt to undermine both the repressive, political constructs known as "nations" and the overreaching dynamic of the national ideology that sustains them. He further observes that these narratives playfully aim at debasing "'holy' borders, international borders as well as the internal lines where narratives of nation are embodied and consecrated" as they begin "to contemplate the ensuing postnational constellations" (IV).

Whether Pynchon's fiction mobilises a "transnational, as opposed to postnational," (Giles 2002, 21) perspective or indeed it proposes a post-national imagination, some critics maintain a position somewhere in between. Stacey Olster has argued that, in Mason Eं Dixon, Pynchon depicts America as "a tenuous and fragile creation" $(2004,297)$ due to, among other things, the fact that "Pynchon writes from a contemporary perspective 
in which the idea of the nation-state has itself been shown to be tenuous and fragile." However, she does not explain why America is represented as "tenuous and fragile" or, for that matter, what this description entails in terms of a postmodern perspective. In 2016, Tore Rye Andersen observed that Pynchon's work obviously “transcends the national framework" (35). Nonetheless, he argues that Pynchon's "globally minded novels" always keep track of "the very real consequences that nation-states have had" in history. He explains that "Pynchon maps the bloody trail" (36) that nation-states have left behind, "rather than merely denying their hegemonic status," in so far as "nations are very much a part of global history."

With all this in mind, perhaps the most significant work in terms of a post-national reading of Pynchon's fiction is Sascha Pöhlmann's 2010 analysis of Gravity's Rainbow and Mason E Dixon. Contrary to Giles' description that Pynchon's fiction depicts a "specifically transnational rather than postnational" imagination (2002, 237), Pöhlmann argues that "these novels do form part of a genuinely postnational imagination since they include but do not remain on the level of the transnational" $(2010,10)$. However, what lacks from Pöhlmann's inspiring study is an examination of similar post-national phenomena in Against the Day. Although he mentions that this novel "constitutes another part of Pynchon's postnational imagination," only briefly does he provide instances where Against the Day suggests a post-national view.

In light of this brief introduction, my paper aims to investigate how Pynchon's fiction from Mason $E^{\circ}$ Dixon to Against the Day depicts a post-national vision that questions the abstract idea of the nation as a metanarrative that has subsumed other narratives in the world. In doing so, I seek to show the representation and development of such a post-national perspective, from Mason E' Dixon to Against the Day, by analysing the alternative worlds in the novels, not least of all the fictive temporal worlds.

\title{
1 The National Order: An Identity "liable to be turned on its head"
}

\author{
Nothing will produce Bad History more directly nor brutally, than drawing a \\ Line, in particular a Right Line, the very Shape of Contempt, through the \\ midst of a People.
}

Thomas Pynchon, Mason E Dixon

The national order is so deeply rooted in the world that for the two past centuries it has become hard "to imagine what a state that is not a nation would look like and how 
it would operate in the contemporary world" (Gupta 1992, 73). Indeed, the national ideology has constantly been used by the nation-state, through a rational discussion of "nation-ness" (Pöhlmann 2010,7), as the single form of arranging the world so as to sustain political power and control. Prasenjit Duara has argued that the dominant narrative of the nation "depicts not only the history of nationalism, but constitutes the master narrative of much modern history, allowing the nation-state to define the framework of its self-understanding" $(1996,151)$. In fact, it is difficult, for instance, to think of the mainstream of twentieth-century political history in categories except the national. As Miroslav Hroch has observed, "the nation has been an inseparable accompaniment of modern European history" (1996, 60). In the modern world, the hegemonic narrative of the nation is represented, by "the practices of the state" (Gupta 1992, 71-72), as "a new kind of spatial and mythopoetic metanarrative, one that simultaneously homogenizes the varying narratives of community while, paradoxically, accentuating their difference.”

If the metanarrative of "nation-ness" (Pöhlmann 2010, 7) has virtually become an always already accepted concept and if it is almost impossible to question its status, there are also good reasons to try to think beyond the national and change the present condition. Mary Layoun has argued that "a national narrative seeks to define the nation, to construct its [...] narrative past in an assertion of legitimacy and precedent for the practices of the narrative present" $(1990,7)$. The key word in Layoun's observation, in my opinion, is the verb construct which reminds us that the national narrative is artificial. It is a hegemonic order, serving nation-states, that is essentialist in nature and imposes its constructed ideology on its singularities. As Stefan Berger has argued, "national master narratives are continually being constructed and reconstructed in contemporary Europe" $(2008,3)$. Since the nature of these narratives of national identity is "constructed," Berger draws attention to "the problematic aspects of constructions of national histories." From the early nineteenth century to the present day, such constructions of national identity have become so commonplace that hardly anyone questions changes in the construction processes over time. After all, "nation is narration" (1) and nation-states decide, in retrospect, which story constitutes the nation. Precisely because the national identity is a contested historical construction, it needs to be superseded by other ways of organising the world that would challenge the all-encompassing metanarrative of "nation-ness" (Pöhlmann 2010, 7).

Charles Carnegie has argued that today the reality of global flows has posed significant problems to nation-states in so far as "the principle of nation-state autonomy is logically incompatible with global interdependence" $(2003,5)$. Indeed, nationalism and the nation-state, in theory and practice, no longer hold as the only sites of sovereignty and 
political power. For instance, Wendy Brown has suggested that "sovereign nation-states no longer exclusively define the field of global political relations" (2010, 24). In what seems a paradox, she observes that "much of the frenzy of nation-state wall building today" is indicative of the decline, "rather than resurgent expressions, of nation-state sovereignty." These views translate into the idea that the nation as the predominant mode of ordering our lifeworlds should be replaced by other ways of interpreting and conceiving of the world. Such a new cognisance would challenge nationalism's essentialised aims and their continued relevance that have become part of popular consciousness across the world. At the same time, the desire to develop alternative ways of organising the world order does not mean that nation-states are no longer powerful, significant agents in the age of globalisation. Indeed, globalisation "has entailed a partial denationalization of national territory and partial shift of some components of state sovereignty to other institutions" (Sassen 1996, XII).

\section{From "number'd and dreamless Indicative" Worlds to "Subjunctive" Worlds: Toward a Post-national Perspective in Mason $6^{\circ}$ Dixon}

One noticeable factor that can play an important role in delegitimising the overruling dominance of "nation-ness" (Pöhlmann 2010,7) in the world is literature. As Pöhlmann brings to our attention, the reason why literary texts can particularly be considered postnational material is "their capability to create worlds instead of describing 'the' world" (19). This holds true especially in postmodernist fiction in so far as its narrative is engaged with questions of ontological nature and, thus, processes of making fictional worlds. Regarding Pynchon, the alternative worlds of his fiction carry considerable weight in opposing the hegemonic dominance of the national order in the world. By invoking national identity, Pynchon directs attention to the long-lasting dominance of "nationsness" (7) in our world and attacks its hegemony by way of offering alternative realties. As an active practice in undermining the national order, this narrative technique can be understood as part of mobilising a post-national perspective in his fiction. In the following passage from Mason $\Xi^{\circ}$ Dixon we can observe the contrast between Britannia, as the site of rationality governed by the national order, and America, as an uncontrolled place of "subjunctive Hopes" (Pynchon 1997, 334) where a post-national vision, in the sense of an alternative future, might be possible:

Does Britannia, when she sleeps, dream? Is America her dream? - in which all that cannot pass in the metropolitan Wakefulness is allow'd Expression 
away in the restless Slumber of these Provinces, and on West-ward, wherever 'tis not yet mapp'd, nor written down, nor ever, by the majority of Mankind, seen,- serving as a very Rubbish-Tip for subjunctive Hopes, for all that may yet be true, - Earthly Paradise, Fountain of Youth, Realms of Prester John, Christ's Kingdom, ever behind the sunset, safe till the next Territory to the West be seen and recorded, mea-sur'd and tied in, back into the Net-Work of Points already known, that slowly triangulates its Way into the Continent, changing all from subjunctive to declarative, reducing Possibilities to Simplicities that serve the ends of Governments,winning away from the realm of the Sacred, its Borderlands one by one, and assuming them unto the bare mortal World that is our home, and our Despair. (334-335)

Pynchon eloquently explains that British colonisers pursued their appropriation of land and property in America where, according to Pöhlmann, open space was turned into "a governable territory" $(2010,223)$ with "a political body of governable people" (177) under the metanarrative of nationalism. This subject is referred to several times in the novel, for instance, through the issues of Indian Wars and slavery. Nevertheless, at issue here is how Pynchon depicts a promising version of America with infinite possibilities that is being changed into a place under the overreaching control of a nationalist order that changes "all from subjunctive to declarative, reducing Possibilities to Simplicities that serve the ends of Governments" (Pynchon 1997, 334). America's open space is shown as the symbol of "subjunctive Hopes" where "'tis not yet mapp'd, nor written down, nor ever, by the majority of Mankind, seen." Captain Shelby, a surveyor in the novel, tells Dixon that in America "pure Space waits the Surveyor,- no previous Lines, no fences, no streets to constrain polygony however extravagant" (566). This suggests the original potential of America as a "subjunctive" (334), rather than "declarative," space of possibility where the all-encompassing dynamic of national ideology has not yet imposed its homogenising goals on her individuals. This also reminds us of Oedipa Maas in The Crying of Lot 49 where the narrator tells us that "she had heard all about excluded middles; they were bad shit, to be avoided" (Pynchon 1966, 113). Oedipa wonders "how had it ever happened here, with the chances once so good for diversity?" Her nostalgic reflection on the possibilities in the past, which no longer seem to hold true in America, is in tune with Mason E Dixon's depiction of America as a space where "diversity," as opposed to nationalism's homogenising force, is possible.

In metaphorical terms, the relation between Great Britain and colonial America is a sort of centre-periphery paradigm where Britannia is trying to appropriate and modify the vast open land at will. Indeed, "all that cannot pass in the metropolitan Wakefulness" 
(Pynchon 1997, 334) of Britannia "is allow'd Expression away in the restless Slumber of these Provinces" in America. In The Crying of Lot 49, Pierce Inverarity is changing the shape of the California landscape by developing a fictional, peripheral town called San Narciso. Similarly, in Mason $\sigma^{\circ}$ Dixon Great Britain is reshaping the American open space of the frontier and its landscape. In fact, Mason and Dixon are mapping the unmapped. In this centre-periphery paradigm of space and power, so to speak, the centrifugal energies of America's open space are subdued by the hegemony of the British national order. As Duara has argued, "the nation is a unique and unprecedented form of community which finds its place in the oppositions between empire and nation, tradition and modernity, and center and periphery" (1996, 151). Pynchon conjures up and criticises nationalism's essentialised, standardising agenda so as to draw attention to the possibility of an alternative America that has been lost at the expense of serving the British government instead of realising the potential of the land's free space.

Mason E'Dixon is a story about the adventures of British astronomer Charles Mason and surveyor Jeremiah Dixon who created the line dividing Pennsylvania from Maryland in order to settle the boundary dispute between them. Colonial America is the main setting of the surveyors' expedition where they carry out measurements to draw the line that will carry their name. As the story is narrated by the Reverend Wicks Cherrycoke, we learn about Mason and Dixon's astronomical and surveying travels to South Africa, Saint Helena, Great Britain, and most importantly the Mason-Dixon line in British North America. A post-national text, the narrative of Mason $E^{\circ}$ Dixon deals with national boundaries as well as what goes beyond them. Indeed, the novel has multiple settings. As part of the Age of Reason, Mason and Dixon bring their message of the Enlightenment to America where they confront irrationality. Implementing their duty to draw the line, they arrive in a colony that is a strange place to them. Mason and Dixon's rational acts, in the face of the fantastic and the irrational, contribute to the demise of the possibilities in America through their national mission to map parts of the land.

Pynchon's novel depicts the way the national order curtails the possibilities and the subjunctive potential in America as Mason and Dixon execute their mission by drawing the line. At the same time, as the characters move from the rationalised, established east to the open, unmapped west in America, the possibility of the existence and coexistence of different modes of thought and life increases. This "subjunctive space of wish and desire" (McHale 2000, 59) mobilises an alternative vision that is post-national in so far as it is not yet "recorded, mea-sur'd and tied in, back into the Net-Work of Points already known" (Pynchon 1997, 334) through the nationalisation of space by the colonies. As such, it is not rationalised, essentialised, homogenised, or for that matter, ordered and 
controlled by the metanarrative of the nation that defines and determines a certain set of aims for its subjects to follow. As we shall see in the following examples, the novel offers the possibility of a post-national understanding of its narrative.

On the island of Saint Helena, Mason is assisting the astronomer Nevil Maskelyne to establish observations of the lunar distance. He tells Mason of an "Invisible Power" (137) to which they are both subject: "We are quite the Pair, then, - that is, I presume, [...], both Subjects of the same Invisible Power? No?” He wonders what Mason thinks of this "Power" and explains that it is "Something richer than many a Nation, yet with no Boundaries." It is an entity that is "never part of any Coalition" with "its own great Army and Navy" which even "allows the Bri-tannick Governance that gave it Charter, to sink beneath oceanick Waves of Ink incarnadine." It is as though this "Invisible Power" were a dynamic system capable of introducing a new order in the world beyond the hegemonic national ideologies of "many a Nation." Maskelyne mentions that this new "Power" is not limited by the restrictive framework of the nations' borders since it has "no Boundaries." It is a ubiquitous system in the world, larger than the overreaching concept of the national order, as it can make "the Bri-tannick Governance ... sink beneath" the ocean.

The new order that the "Invisible Power" could introduce to the world is the suggestion of an alternative reality in the novel where Pynchon's narrative draws attention to a possible post-national vision. Mason $\Xi^{\circ}$ Dixon is overwhelmingly expressive of British and Dutch colonialisms and, for that matter, indicative of European nationalisms in their colonial agenda to surpass one another. In a nationalised world, this short scene from the novel can emphasise the possibility and the need to supersede the fundamental dominance of "nations-ness" (Pöhlmann 2010, 7), in practicing its restricting political agenda, by other ways of interpreting and arranging the world. These other modes of understanding, perhaps including the "Invisible Power" (Pynchon 1997, 137), would offer different epistemological interpretations of the world that value choice over constraint. In doing so, they mobilise a post-national imagination.

When Mason arrives in Brooklyn, together with a girl named Amelia, he comes across a gang of thieves who hate "the English King and all his subjects" (387). The gang members believe that England's taxation policy in America is unfair. One of them, called Drogo, tells Mason that "the only use we can be to them, is as a Herd of animals" (388) because "all the Brits want us for, is to buy their Goods." They think that Britain's tax policy is "simple Tyranny" (391) and they must resist British control in America. Feeling shocked at how they feel about the Stamp Act, Mason explains that he works under contract for the king of England to enact his mission in America. Amelia is amased at Mason's important expedition, "working directly for the King" (392). Mason responds, 
"Alas, no longer. Out in the Woods these days, running lines for a couple of Lords in a squabble." She mentions that the surveyors' job in America is useless in so far as it will be soon undone: “'An exercise in futility! I can't believe you Cuffins! In a few seasons hence, all your Work must be left to grow over, never to be redrawn, for in the world that is to come, all boundaries shall be eras'd"' (393). Amelia believes that there will be a new world where the borders and boundaries will be removed.

Until this point in the novel, Pynchon has much dwelled on the issue of colonialism and its dominance in the colonies such as the Cape of Good Hope and America. Pynchon demonstrates the hegemony of British colonialism in America that has seized and transformed open space into a controllable place. Such a national order determines the ways of arranging societies and forces the citizens to consider their established, homogenising standards. The narrator relates that "when word arriv'd of the first Conestoga Massacre, neither Astronomer quite register'd its full Solemnity” (296). Indeed, Mason does consider "as peculiar, that the first mortal acts of Savagery in America after their Arrival should have been committed by Whites against Indians.” Mason and Dixon have seen "white Brutality enough, at the Cape of Good Hope. They can no better understand it now, than then." In fact, "Whites in both places are become the very Savages of their own worst Dreams, far out of Measure to any Provocation." However, in the brief exchange between Mason and Amelia, the novel suggests an alternative future possibility that can be understood in terms of a post-national imagination. Although England's national ideology prevails in America, Amelia's observation underscores the idea that in the world to come the hegemonic dominance of the metanarrative of "nations-ness" (Pöhlmann 2010,7) will be made futile in so far as "all boundaries shall be eras'd" (Pynchon 1997, 393).

\section{Against the Day's Nationalised World}

Against the Day spans the years between the Chicago World's Fair of 1893 and the early 1920s. An "encyclopedic" $(1976,1)$ novel, to use Edward Mendelson's words, its narrative engages in various places around the world, including Colorado, London, Göttingen, New York, Central Asia, Siberia at the time of the mysterious Tunguska Event, Mexico during the Revolution, Vienna, the Balkans, silent-era Hollywood, post-war Paris, and, to cite from Pynchon's dust jacket, "one or two places not strictly speaking on the map at all." There is a "sizable cast" of fictional and historical characters such as scientists, mathematicians, shamans, anarchist bombers, miners, and capitalist bosses. Pynchon tells us that these characters "are mostly just trying to pursue their lives" as they 
are confronted with "a worldwide disaster looming just a few years ahead." We also learn from his description of the novel, on the front inner flap of the dust jacket, that several "obscure languages are spoken" and "contrary-to-the-fact occurrences occur" throughout the narrative. He concludes his description with the rather hopeful suggestion that "maybe it's not the world, but with a minor adjustment or two it's what the world might be."

In this vast panorama of various interesting issues, Against the Day offers critical insights through which the legitimacy of the metanarrative of "nation-ness" (Pöhlmann $2010,7)$ is questioned. For instance, Ratty McHugh's analysis, on the verge of World War I, suggests the crisis of the nation-state:

Today even the dimmest of capitalists can see that the centralized nationstate, so promising an idea a generation ago, has lost all credibility with the population. Anarchism is now the idea that has seized hearts everywhere, some form of it will come to envelop every centrally governed societyunless government has already become irrelevant through, say, family arrangements like the Balkan zadruga. If a nation wants to preserve itself, what other steps can it take, but mobilize and go to war? Central governments were never designed for peace. Their structure is line and staff, the same as an army. The national idea depends on war. (942)

A British anarchist in the novel, who has abandoned government work, Ratty observes that when it becomes clear to the capitalists that the nation-state is no longer popular, they try to preserve their old ideology through a different strategy. War needs to be created in order to revitalise the national idea. As J. Paul Narkunas has argued, "the use of war to create friction between peoples destabilizes alternative arrangements such as anarchism" (2011, 250), which was "challenging the sovereign nation-state leading up to World War I." In fact, Ratty believes that in a "general European war" (Pynchon 2006, 942) anarchists "would be the biggest losers" in so far as war is the necessary apparatus to sustain the national order. A metanarrative of homogeneity, the nation-state attempts to curtail the power of anarchists who hold a sustained scepticism toward its conforming aims. Seeking to establish uniformity and linearity, so as to exert all-encompassing control over its singularities, what the nation-state desires is "a nation of starers [...], a being They assembled, a being They would dismantle” (Pynchon 1973, 374).

The above example suggests how the national order has shaped the general framework of the world and has persistently sought to define and determine our lifeworlds. The exercise of its dominant ideology, by nation-states, for so long has left no space for other epistemological understandings of our world or, for that matter, any alternative ways of 
organising it in terms of ontological possibilities. This passage points to the fact that the narrative of the nation is not necessarily an order that is based on the common good of its subjects but one that imposes its hegemonic ideology on communities and their individuals.

If Pynchon's novel shows that nation-states use war to maintain the national order, it also suggests certain ways to challenge its overreaching dominance in the world. His alternative realities set in motion an imagination free from the hegemonic restrictions of a standardising metanarrative where a post-national understanding becomes possible. Such a post-national vision allows for the reimagination of our world that has been enveloped by the absolutist order of the nation. In order to resist the hegemony of the present calcified world order, according to Ratty's explanation in the novel, it is important to go anarchic and transcend the national ideology. For example, governments can be replaced by "other, more practical arrangements" (Pynchon 2006, 937). Nevertheless, Pynchon's character is aware that anarchism should not destroy things but play "more of a coevolutionary role, helping along what's already in progress." As Graham Benton has argued, "while Pynchon frequently invokes a concept of anarchism [...] as a valued political philosophy, he is also wary of fully endorsing an anarchist position because he recognizes such a position to be open to any number of violent corruptions and betrayals" $(2011,191)$.

Against the Day provides the reader with a host of passages where a post-national imagination is suggested. Early in the text, Darby tells Chick about the Garcons de '71, a rival band of boy adventurers to the Chums of Chance, who were formed during the 1871 sieges of Paris when balloons were the only way to communicate with the city. During the sieges, some of these balloonists came to realise "how much the modern State depended for its survival on maintaining a condition of permanent siege-through the systematic encirclement of populations, [...], the relentless degradation of civility until citizen was turned against citizen, even to the point of committing atrocities like those of the infamous pétroleurs of Paris" (Pynchon 2006, 24). Narkunas has observed that here "Pynchon does not chart nation-states as sovereign legal entities that command or direct force in the name of national identities, and to whom citizens can turn for protection" $(2011,243)$. What, in fact, he seeks to do is to highlight "contested forces, as well as specific elements monopolizing or deploying force on a regional or national scale through a sense of perpetual threat-that is, the 'permanent siege' of war generalized in the creation of society." However, with the end of the sieges the balloonists were set free of "the political delusions" (Pynchon 2006, 24) and, as Penny mentions, decided to fly beyond "national boundaries, running blockades, feeding the hungry, sheltering the sick and persecuted." As Pöhlmann has argued, the elevated viewpoint of the balloonists 
let them broaden their "framework of thought" $(2010,362)$ by way of observing the big picture of "politics and society that could not remain within the accepted national categories.”

The Chums of Chance represent U.S. national identity. Each time in the novel they encounter the flagship of their "mysterious Russian counterpart-and, far too often, nemesis-Captain Igor Padzhitnoff” (Pynchon 2006, 127), "lively though anxious memories" are evoked in the boys. Nevertheless, albeit late, in the end the Chums recognise the limits of their national identity based on an us-them conception of sameness and difference. The national ideology that has determined their identity, against the Russian squad, and defined their story line until then becomes irrelevant. In fact, both groups begin to provide Europeans with provisions to alleviate their suffering during the First World War. Nathalie Aghoro has argued that for the boys "cooperation is their option for the excluded middle that nationalist ideology cannot acknowledge in its fight for supremacy" $(2009,49)$. Since the nations of the world do not leave frontiers behind, the boys use the sky "in order to help a world that is threatened to resolve into fragments under the impression of World War." Aware of the limitations of their national identity, they act post-nationally, beyond the borders of nations, to keep the world safe.

\section{Transcending "the map-space of two dimensions, by climbing into the third": Post-national Visions in Against the Day}

In Against the Day, the sky becomes the symbol of post-national cooperation in the last pages of the novel where the national boundaries are challenged, if not dismantled. This alternative possibility represents a "supranational idea" (Pynchon 2006, 1087) in the novel. In the annual convention initiated by the French group of balloonists, the Garçons de '71 up above the skies in Paris, Penny explains the concept of "the supranational idea" to the Chums of Chance. It is "literally to transcend the old political space, the map-space of two dimensions, by climbing into the third." As such, it has the capability to transcend the nation-state's calcified order in the world that has imposed its overreaching ideology on societies. In the end, the Garçons de ' 71 refuse to work with any national or state forces on the ground. They decide to "fly wherever they're needed, far above fortress walls and national boundaries" (24). In this scene, Pynchon underscores the need for an alternative interpretation and arrangement of the world in a different manner than the homogenising ideology of the nation. "The supranational idea" (1087) heralds that new alternatives, such as the "third dimension," might be pos- 
sible. Pynchon's alternative realities seek to counter the hegemonic identity formation of "nation-ness" (Pöhlmann 2010,7) by providing a post-national perspective.

Freed from the restrictive framework of their duties, the Chums of Chance fly over the national boundaries and help whoever they wish. They find a post-national order "above the City in a great though unseen gathering of skyships" (Pynchon 2006, 1087) where their identity is no longer defined by the national ideology. The "supranational idea" is "there," even if "invisible," and directs the Chums toward "grace" (1089). As the boys' motto indicates, there is an alternative possibility that transcends the national framework: "There, but Invisible” (1087). This suggests a different understanding of the world. "No one aboard Inconvenience has yet observed any sign of this" (1089) but "they know-Miles is certain -it is there." The boys are ready "for the glory of what is coming to part the sky. They fly toward grace.” In this passage, it is as though the nation-state's overruling hegemony had been cancelled out by a new world order. This alternative reality, inside a limited system, is what post-nationalism attempts to build. The Chums are equipped with a new understanding of the world other than the calcified rule of "nation-ness" (Pöhlmann 2010, 7) that has left no freedom to imagination. Pynchon seems to be telling us that "there are no preexisting, transcendent structures or a priori concepts of power and organization that persist for the two main forces of capitalism and governance" (Narkunas 2011, 260-261). Notwithstanding the dawn of one the most devastating wars in human history, in the end, the post-national vision of the novel invites us to reimagine the world by challenging the long-lasting metanarrative of the nation.

When Against the Day was first published in 2006, it received mixed reviews from critics. While it was lauded for its encyclopaedic range and intelligence, some critics found the novel to be inaccessible and confusing for the reading market. Nevertheless, ever since its publication, scholars have increasingly been appreciating the novel's originality and genius. On that score, a significant factor that speaks to the idea of originality is how Pynchon uses certain narrative techniques to demonstrate and deconstruct the nation-sate as a dominant force arranging and ordering the world. For instance, using the genre of boys' adventure fiction, Pynchon shows how the national idea surfaces in the novel in the period leading to the First World War. From the very outset, the Chums' geographical mobility across the sky provides the reader with an idea of the national order in the organisation of Chicago's White City, especially the 1893 World's Fair. At the same time, the use of this genre, among many others in the novel, opens to the reader an imagination beyond the static rule of the national idea. As it becomes clear in Pynchon's novel, refusing to work with any nation-state authority on the ground, the boys use the sky to help populations in need and take action to comfort their suffering during 
World War I. Irrespective of the duties dictated by their "National Office" (1023), their increasing assertion of free will counters the hegemonic stance of the national ideology and suggests a post-national imagination in the narrative world of Against the Day. As Christopher Leise has argued, Against the Day's "highest genius lies in the ability to occupy so many genres of American ideological indoctrination to dramatically repurposed effect” (2011, 4), including a post-national vision.

\section{Conceptions of Time and the Alternative Worlds in Against the Day}

Lateral world-sets, other parts of the Creation, lie all around us, each with its crossover points or gates of transfer from one to another, and they can be anywhere, really....

Thomas Pynchon, Against the Day

In the Hotel Borealis, the Headquarters of the Vormance Expedition to the Arctic in Against the Day, Dr. Vormance, on sabbatical from Candlebrow University, and his fellow scientists are arguing the issues of Quaternionist theory and time. As "THE TRANSNOCTIAL DISCUSSION GROUP” (Pynchon 2006, 135) meets in the basement of the hotel to discuss "the Nature of Expeditions," Dr. Vormance makes a case for colonising time: "And what of colonizing additional dimensions beyond the third? Colonize Time. Why not?” In the scene that immediately ensues, the narrator recounts that some members of the Expedition had visited the great Library of Iceland where they could find The Book of Iceland Spar. From the librarian there, they learn that Iceland spar, as "the genuine article," is "the sub-structure of reality" in Iceland:

For this is not only the geographical Iceland here, it is also one of several convergences among the worlds, found now and then lying behind the apparent, like these subterranean passages beneath the surface, which lead among the caves of Iceland spar [...] by light. Down where the 'Hidden People' live, [...] Iceland spar is what hides the Hidden People, makes it possible for them to move through the world that thinks of itself as 'real.' $(137-138)$

Through Iceland spar Pynchon creates a subterranean world, even a convergence "among the worlds," parallel to ours where the "Hidden People" live and think of their world 
as the "real" one. What is intriguing about this alternative world, "alongside our own world," that cannot "be seen" is that these people "have been crossing here, crossing over, between the worlds, for generations. [...] Looking back over a thousand years, there is a time when their trespassings onto our shores at last converge, as in a vanishing-point, with those of the first Norse visitors." The librarian makes it clear that the "Hidden People" trespassed onto our world frequently until a time when their trespassings converged with the arrival of the first Norse visitors. At that "vanishing-point" the two different times in the two different worlds converged.

Returning to Pynchon's alternative worlds, a notable subject regarding his fiction is the relation between these multiple worlds and the issue of time. The above passage does not offer much in the way of a post-national vision. However, I have chosen this scene to emphasise the way that Against the Day instantiates the issue of temporality, in relation to the question of alternative realities, which helps spell out my argument in terms of a post-national imagination in the novel. As Inger H. Dalsgaard has argued, "Against the Day can be said to expand, diffuse, or broaden definitions of time and temporal transport to involve theoretical, mental, spiritual, and existential senses of those concepts" (2011, 115-116). With temporality in mind, as a pivotal issue in Pynchon's novel, I endeavour to depict how Against the Day's multiple worlds offer an alternative historical perspective which challenges the long-standing hegemony of nationalism in the world.

\section{From Mason $\Xi^{2}$ Dixon to Against the Day: A Post-national Panorama through Historical Continuity}

At least three of Pynchon's novels are narratives that reflect upon the way our world has been shaped throughout history. As Amy J. Elias has argued, what Pynchon's three longest historical novels have in common is that they "imply a philosophy of history, or meditations on the nature of history itself" $(2012,124)$. Similarly, Andersen has proposed the term "world-historical or global novels" $(2016,8)$ to refer to Pynchon's bigger texts that "stand clearly apart from the rest of his work" (24). He explains that "the remarkable unity of their vision" mobilises a historical perspective that "maps the complexity" of significant historical transition points in the novels. In light of these views, I intend to demonstrate a continuity in the perception of time from Mason E Dixon to Against the Day which highlights Pynchon's post-national imagination.

World War I is a salient issue in Against the Day. However, Pynchon's novel does not say as much about the war as it does about its implications, including history and systems 
of control and order. Nicholas Nookshaft is the Grand Cohen of the London chapter of "The T.W.I.T., or True Worshippers of the Ineffable Tetractys" (Pynchon 2006, 224), in the novel. He explains "his personal concept of the Psychical Detective" (227) to Lew Basnight, "The 'spotter' from White City Investigations" (41). It is a complicated mystical system, based on the Tarot, which offers a complex explanation for evil. The Cohen mentions that there is one particular case which is preoccupying them. Its twentytwo suspects "are precisely the cadre of operatives who, working in secret, cause-or at least allow-History upon this island to happen, and they correspond to the twentytwo Major Arcana of the Tarot deck" (227). He elaborates that the twenty-two cards of the Major Arcana "might be regarded as living agencies, positions to be filled with real people," and "when vacancies occur, [...] new occupants will emerge, obliging" them to "learn their histories as well." The history that these twenty-two suspects are trying to cause to happen on the island is a way to suggest an alternative historical perspective. Indeed, when Lew asks the Cohen what the nature of their crime would be, he explains that they are committing some sort of "an ongoing Transgression, accumulating as the days pass, the invasion of Time into a timeless world" (228). The "ongoing Transgression" is "History if you like," suggests the Cohen. Hence, the temporal transgressions of these twenty-two people make a version of history happen on the island that is the suggestion of an alternative historical vision. This new understanding questions the artificial formation of the overreaching narrative of history as we know it, which becomes a dominating tool serving the goals of nation-states.

In Mason $E^{\circ}$ Dixon, eighteenth-century America is depicted as an open space where we observe an ongoing struggle for dominance between the advocates of the controlling order of rationalisation and the subjunctive forces of irrationality. Set almost a century and a half later, Against the Day evinces the consequence of this conflict between the powers of "totalization" (Elias 2012, 130) and counter hegemonic forces proposing "openness and improvisation," as the narrative approaches World War I. In effect, in Mason E' Dixon, Pynchon offers an alternative formation of America's history by calling into question its founding myths. Concentrating on the line, he highlights America's open space as one of potential in contrast to the declarative forces of homogenisation. This historical contemplation, as to what the future of the territory might be, tickles our imagination regarding America's treatment of open space, be it the case of killing Indians or settling down the slavery dispute between the slave-holding colonies and those that banned it.

Going back to the year 1763, Pynchon sets in motion an alternative history where the making of America has been challenged. As we move from the eighteenth century, when Mason and Dixon started their surveying project, to the timeline between 1893 
and the beginning of World War I in Against the Day, we still observe a continuity in the hope for that subjunctive formation of the world. This is most obvious, but not exclusively, through the concept of "the supranational idea" $(2006,1087)$ presented in the last pages of the novel. Against the Day's alternative realities demonstrate a continuity in the time relation with Mason $\Xi^{2}$ Dixon, as one of the main concerns of Pynchon in his bigger historical novels. Nevertheless, the confrontation of the forces of control and anarchy in the novel leads to World War I. This disastrous incident radically shatters our cognisance of the concepts of time and space in the world. However, from the eighteenth-century colonisation of America's open space to the onset of World War I, As Charles Mason says in the novel, "another Dispensation of Space ... and Time” (1997, $419)$ is taking shape. This new spatiotemporal organisation enables a continuity from Mason $E^{2}$ Dixon to Against the Day, in terms of the instantiation of an alternative historical view, that contributes to a consistent post-national reading of the novels.

\section{References}

Adams, Rachel. 2007. “The ends of America, the ends of postmodernism.” Twentieth Century Literature 53(3): 248-272.

Aghoro, Nathalie. 2009. "Bilocated Identities: Taking the Fork in the Road in Against the Day." Aspeers.

Andersen Tore Rye. 2016. “Mapping the World: Thomas Pynchon's Global Novels.” Orbit: A Journal of American Literature 4(1). doi: https://doi.org/10.16995/orbit.178

Ashline, William L. 1995. "The Problem of Impossible Fictions.” Style 29(2): 215-234.

Benton, Graham. 2011. "Daydreams and Dynamite: Anarchist Strategies of Resistance and Paths for Transformation in Against the Day.” In Pynchon's Against the Day: A Corrupted Pilgrim's Guide, edited by Jeffrey Severs and Christopher Leise, 167-190. New York: University of Delaware Press.

Berger, Stefan. 2008. "Narrating the Nation: Historiography and Other Genres." In Narrating the Nation: Representations in History, Media and the Arts, edited by Stefan Berger, Linas Eriksonas, and Andrew Mycock: 1-16. New York: Berghahn Books.

Brown, Wendy. 2010. Walled States, Waning Sovereignty. Cambridge: MIT Press.

Carnegie, Charles V. 2003. Postnationalism Prefigured: Caribbean Borderlands. Piscataway: Rutgers University Press.

Cowart, David. 2011. Thomas Pynchon and the Dark Passages of History. Athens: University of Georgia Press.

Dalsgaard, Inger H., Luc Herman, and McHale, Brian. 2012. The Cambridge Companion to Thomas Pynchon. Cambridge: Cambridge University Press. 
Duara, Prasenjit. 1996. "Historicizing National Identity, or Who Imagines What and When." In Becoming National: A Reader, edited by Geoff Eley and Ronald Grigor Suny, 151-178. Oxford: Oxford University Press.

García-Caro, Pedro. 2014. After the Nation: Postnational Satire in the Works of Carlos Fuentes and Thomas Pynchon. USA: Northwestern University Press.

Giles, Paul. 2002. Virtual Americas: Transnational Fictions and the Transatlantic Imaginary. Durham: Duke University Press.

Gupta, Akhil. 1992. "The Song of the Nonaligned World: Transnational Identities and the Reinscription of Space in Late Capitalism.” Cultural Antbropology 7(1): 63-79.

Hroch, Miroslav. 1996. "From National Movement to the Fully-Formed Nation: The NationBuilding Process in Europe.” In Becoming National: A Reader, edited by Geoff Eley and Ronald Grigor Suny, 60-77. Oxford: Oxford University Press.

Jameson, Fredric. 1991. Postmodernism, or, The Cultural Logic of Late Capitalism. Durham: Duke University Press.

Layoun, Mary. 1990. "Narrating Nationalism: Who Speaks and How? Who Listens and How? Or, Whose Story is this Anyway.” Unpublished MS.

Leise, Christopher. 2011. "Introduction: Exceeding the Usual Three Dimensions: Collective Visions of the Unsuspected.” In Pynchon's Against the Day: A Corrupted Pilgrim's Guide, edited by Jeffrey Severs and Christopher Leise, 1-14. New York: University of Delaware Press.

Liner James. 2016. "Utopia and Debt in Postmodernity; or, Time Management in Inherent Vice.” Orbit: A Journal of American Literature 4(1). doi: https://doi.org/10.16995/orbit.174

McHale, Brian. 2000. Mason EDixon in the Zone, or, A Brief Poetics of Pynchon-Space. Newark: University of Delaware Press.

McHale, Brian. 1987. Postmodernist Fiction. London: Routledge.

Mendelson, Edward. 1976. “Encyclopedic Narrative: From Dante to Pynchon.” MLN.

Narkunas, Paul J. 2011. "Europe's 'Eastern Question' and the United States' 'Western Question': Representing Ethnic Wars in Against the Day.” In Pynchon's Against the Day: A Corrupted Pilgrim's Guide, edited by Jeffrey Severs and Christopher Leise, 239-264. New York: University of Delaware Press.

Olster, Stacey Michele. 2004. "A 'Patch of England, at a three-thousand-Mile Off-set'? Representing America in Mason \& Dixon.” Modern Fiction Studies 50 (2): 283-302.

Pavel, Thomas. 1981."Tragedy and the Sacred: Notes Towards a Semantic Characterization of a Fictional Genre.” Poetics 10 (2-3): 234.

Pöhlmann, Sascha. 2010. Pynchon's Postnational Imagination. Heidelberg: Winter.

Sassen Saskia. 1996. Losing Control?: Sovereignty in the Age of Globalization. New York: Columbia University Press.

Wark, McKenzie. 2004. A Hacker Manifesto. Cambridge, MA: Harvard University Press. 